\title{
EFFORT ESTIMATION MODELING OF E-GOVERNMENT APPLICATION DEVELOPMENT USING FUNCTION POINTS BASED ON TOR AND SRS DOCUMENT
}

\author{
Noorlela Marcheta, Irman Hermadi, Yani Nurhadryani \\ ${ }^{1}$ Jakarta State Polytechnic, Depok, Indonesia \\ ${ }^{2,3}$ Bogor Agricultural University, Bogor, Indonesia \\ 1ela.marcheta@tik.pnj.ac.id, ${ }^{2}$ irmanhermadi@apps.ipb.ac.id, ${ }^{3}$ yhadryani@gmail.com
}

\begin{abstract}
Software cost estimation is important for information systems management and is generally taught in software engineering courses especially to terms of the ever-increasing development of E-Government. A significant challenge for Software Sizing (SS) is to determine cost estimates based on TOR documents that do not yet contain complete Software Requirements Specifications (SRS). This study uses Function Points as one of the measurement methods that can make cost estimates and expert needs based on the desired functional system. On the other hand, there are cases where estimation needs after the SRS document have been made. Thus in this study, the authors discuss the implementation of SS based on TOR and SRS documents for E-Government. The results of this study indicate the closeness of the actual and estimated values of $81.9 \%$ for TOR and $93.4 \%$ for SRS.
\end{abstract}

Keywords: effort estimated; e-government; function point; software matrix.

\section{INTRODUCTION}

The most important problems that must be solved by software developers and users is to predict the size of the programing system and development efforts [1]. Then, the need for system engineering practices is increasing so it needs to be explored tightly, especially in the estimated cost [2] This cost will utilize a variety of very important resources and must be managed for the success project, especially when going to submit a TOR to the control of funds spent during the project. This study has a purpose to plan management and control of resources of man, time, and cost [7]. Thus the accuracy of the estimated cost can be a determinant of successful software development.

The next challenge is the difference in perspective against software measurements were also behind this research. First, the software developer approaches the estimated cost still does not have a certain standard. This is due to the lack of detail or accuracy equation in pricing so that the important factors be difficult to be presented. Meanwhile, from the user, the determination of the value of the cost to be a software development rated difficult because it is abstract. This is in line with Pranatha (2012) research that there are two problems commonly faced in estimating, over-estimated that caused financial loss and under-estimated which will cause that systems built with fewer components and less supportive and will result in losses directly against the good name of an institution [11].

Estimation techniques cost has been developed among others, in terms of efficiency [3], the implementation of the Use Case Point [13], and the incorporation of methods FP to approach non-algorithmic [4][16]. This study aims to make an effort estimation model which can be derivation into cost estimates and man-days using Function Points based on documents of TOR (Term of Reference) and SRS (Software Requirements Specification).

Contributions of this research are to construct cost estimation modeling standards on the software developing method is simple, clear, and defined from the planning stage where the processing software time can be adjusted. The advantages of this research are expected to help the government in each Ministry / Agency and Local Government in the creation of the TOR. Because the current government has required all government and public institutions to take advantage of information technology to the interests of public service and administration [17]. Because the current government has required all government and public institutions to take advantage of information technology to the interests of public service and administration [17]. This paper consists of four sessions, the first session contains an introduction, the second session is a method used to model cost estimates based on TOR and SRS documents, and the third session explains the results of the proposed model and the comparison of estimated costs with actual values (TOR and SRS) and the last is the conclusion.

\section{MethodE}

This research uses a case study on four e-government applications from Dinas Komunikasi Informatika dan Persandian Kota Bogor (DISKOMINFO) because egovernment data is considered to be more accurate and complete. This study uses technical documentation (TOR and SRS), contract documents, and TCF assessment forms from the development of e-government systems at the catalog and transaction stages. The proposed estimation process using Function Point (FP). Where the measurement of FP can be obtained through (1).

$\mathrm{FP}=\mathrm{UFC} \times \mathrm{TCF}(1)$

Where :

$\mathrm{FP}=$ Total Function Point

UFC $=$ Total Udjusted Function Points 


\section{TCF $=$ Total Technical Complexity Factor}

Total Unadjusted Function Points Count (UFC) is used to measure information processes involving five information domains, i.e. External Input (EI), External Output (EO), External Inquiries (EQ), Internal Logical File (ILF) and External Interface File (EIF). Each type can be defined as follows:

1. EI, data types relating to the user interface in entering data into the application.

2. EO, data types relating to the output that the application generates for the user (printed reports or screen layouts). In this context, EO refers to reports, screens, error messages, and so on.

3. EQ, the type of query/search/view associated with the query is an online input that generates instantaneous software responses in the form of online output that is often obtained from an ILF.

4. ILF, file/table/database type related to data storage logic in the form of a file or some kind of relational database.

5. EIF, data types (output or input) that can be related to computers through data communication on other devices or machines.

The calculation of each domain depends on the level of complexity of these components. IFPUG (International Function Point Users Group) has made a procedure to determine the level of complexity of components, namely low, medium, and high. The categorization of components is based on DET, RET, and FTR calculations which are defined as follows [10] :

1. Data Element Type (DET): A data element that is known by the user (non-repeatable data field). Example: Customer Name, No. Customer, Date of Birth, etc.

2. Record Element Type (RET): Subgroup of data known by the user. For example, customer data consists of biodata, financial data, family dependent data

3. File Type Reference (FTR): ILF that is read or accessed by an elementary process (EI / EO / EQ), or EIF that is read by an elementary process.

In theory, there are 15 different item variations from five domains of software information and has three different levels of complexity. This calculation is complete by multiplying the number of items in each variation with the weight of variation and summing 15 items (Fenton, 1997). The UFC calculation equation is shown in (2).

$$
\mathrm{UFC}=\sum_{\mathrm{i}=1}^{15}\left((\text { Number of items of variety } i) \mathrm{x} \text { weight } t_{\mathrm{i}}\right)
$$

Then the TCF calculation through (3) is summing the scores obtained from the 14 general criteria of the system which can be seen in Table 7 . Each criterion weights according to its complexity, namely 1 for the smallest effect to a value of five (5) for the most powerful effect and a value of zero (0) if it does not influence at all.

Additionally, be sure your sentences are complete and that there is continuity within your paragraphs. Check the numbering of your graphics (figures and tables) and make sure that all appropriate references are included [15].

$$
\mathrm{TCF}=0.65+0.01 \sum_{\mathrm{i}=1}^{14} \mathrm{~F}_{\mathrm{I}}
$$

Where :

TCF: Technical Complexity Factor $F_{i}$ : Factor-i

The following are the steps for calculating cost estimates:

Stage 1. Identify the function of the e-government system that will be developed.

Stage 2. Each system function, classified into one type of information domain, namely: EI, EO, EQ, ILF or EIF

Stage 3. Determine the level of complexity in each functional system based on Table 2 for EI, Table 3 for EO / EQ and Table 4 for ILF / EIF

Stage 4. Calculating UFC value

Stage 5. Multiply the number of each domain, then multiply by the weight

Stage 6. Determine the TCF value

Stage 7. Calculate the value of FP (Adjust FP)

Stage 8. Calculate the man-month estimate

Stage 9. Calculate the estimated time the project is taken based on the ISBSG (International Software Benchmarking Standards Group) [6].

TABLE I

The complexity level of EI based on DET and FTR

\begin{tabular}{cccc}
\hline \multirow{2}{*}{ FTR } & \multicolumn{3}{c}{ DET } \\
\cline { 2 - 4 } & $\mathbf{1 - 4}$ & $\mathbf{5 - 1 5}$ & $>\mathbf{1 5}$ \\
\hline $\boldsymbol{2} 2$ & Low & Low & Average \\
$\mathbf{2}$ & Low & Average & High \\
$>\mathbf{2}$ & Average & High & High \\
\hline
\end{tabular}

Source: Uzzafer (2016) [15]

TABLE II

The complexity level of EO/EQ based on DET and FTR

\begin{tabular}{cccc}
\hline \multirow{2}{*}{ FTR } & \multicolumn{3}{c}{ DET } \\
\cline { 2 - 4 } & $\mathbf{1 - 5}$ & $\mathbf{6 - 1 9}$ & $>\mathbf{1 9}$ \\
\hline $\mathbf{0 - 1}$ & Low & Low & Average \\
$\mathbf{2 - 3}$ & Low & Average & High \\
$>\mathbf{3}$ & Average & High & High \\
\hline
\end{tabular}

Source: Uzzafer (2016) [15]

TABLE III

The complexity level of ILF/EIF based on DET and RET

\begin{tabular}{cccc}
\hline \multirow{2}{*}{ RET } & \multicolumn{3}{c}{ DET } \\
\cline { 2 - 4 } & $\mathbf{1 - 1 9}$ & $\mathbf{2 0 - 5 0}$ & $>\mathbf{5 0}$ \\
\hline $\mathbf{0 - 1}$ & Low & Low & Average \\
$\mathbf{2 - 3}$ & Low & Average & High \\
$>\mathbf{3}$ & Average & Tinggi & High \\
\hline
\end{tabular}

Source: Uzzafer (2016) [15] 


\section{RESULT AND DISCUSSION}

For this proposed model, the estimated cost based on the TOR document requires a pre-processing stage carried out to estimate the general software information process. Estimators who have basic IT are highly recommended for this stage. Furthermore, the process is carried out following the FP stages. Starting from the identification of e-government system functions, UFC calculations, TCF to be able to produce output values man-month. This man-month requirement will be a reference for estimating the cost and total man needed for software development. Estimation models can be seen in Fig 1.

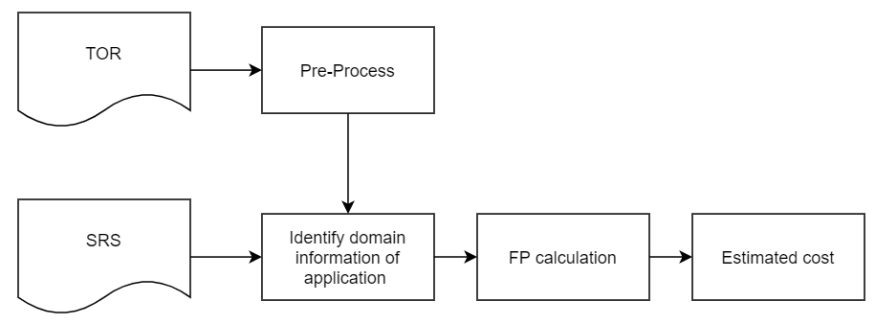

Fig. 1. Cost estimation proposed model

\section{A. Mandays Estimated Using the Proposed Model}

The results of a comparison of estimation using FP with actual cost based on SRS documents can be seen in Table IV that shows the results of the proximity of $93.4 \%$ and estimates based on TOR documents can be seen in Table $\mathrm{V}$ that shows the results of the proximity of $81.9 \%$. This model can estimate software costs with standards that follow man-days. The more man-day of work required, the more expensive.Comparison of estimated and actual prices

TABLE IV Comparison of Actual and Estimates Cost based on TOR

\begin{tabular}{|c|c|c|c|c|c|}
\hline No & $\begin{array}{l}\text { Application } \\
\text { Name }\end{array}$ & Mandays & $\begin{array}{l}\text { Actual Cost } \\
\text { (IDR) }\end{array}$ & $\begin{array}{c}\text { Estimatio } \\
\text { n Cost } \\
\text { (IDR) }\end{array}$ & $\begin{array}{c}\text { Percentage } \\
(\%)\end{array}$ \\
\hline 1 & Aspirasi Online & 340 & $40,500,000$ & $48,262,500$ & 80.0 \\
\hline 2 & Digital Profile & 368 & $45,150,000$ & $53,925,000$ & 80.6 \\
\hline 3 & $\begin{array}{l}\text { SIM Peme- } \\
\text { rintahan }\end{array}$ & 346 & $41,050.000$ & $51,000,000$ & 75.8 \\
\hline 4 & SIM E-Wilayah & 354 & $47,630.000$ & $52,125,000$ & 90.6 \\
\hline \multicolumn{5}{|c|}{ Average Percentage (\%) } & $81.9 \%$ \\
\hline
\end{tabular}

TABLE V

Comparison of Actual and Estimates Cost based on SRS

\begin{tabular}{c|l|r|r|r|r}
\hline No & \multicolumn{1}{|c|}{$\begin{array}{c}\text { Application } \\
\text { Name }\end{array}$} & Mandays & $\begin{array}{c}\text { Actual Cost } \\
\text { (IDR) }\end{array}$ & $\begin{array}{c}\text { Estimation } \\
\text { Cost (IDR) }\end{array}$ & $\begin{array}{c}\text { Percentage } \\
(\%)\end{array}$ \\
\hline 1 & Aspirasi Online & 314 & $40,500,000$ & $44,625,000$ & 89.8 \\
\hline 2 & Digital Profile & 327 & $45,150,000$ & $48,750,000$ & 92.0 \\
\hline 3 & $\begin{array}{l}\text { SIM Peme- } \\
\text { rintahan }\end{array}$ & 244 & $41,050,000$ & $41,250,000$ & 99.5 \\
\hline 4 & SIM E-Wilayah & 349 & $47,630,000$ & $51,375,000$ & 92.1 \\
\hline \multicolumn{5}{c}{ Average Percentage (\%) } & $\mathbf{9 3 . 4 \%}$ \\
\hline
\end{tabular}

\section{B. Comparison of Estimated and Actual Cost}

Cost comparison chart in Fig. 2 and Fig. 3 shows that the estimated cost value using the proposed model approaches an actual value. So that this model can be used to estimate software development.

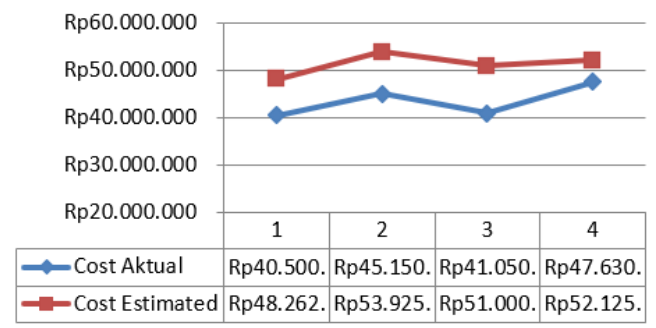

Fig. 2. Comparison of estimated and actual cost based on TOR document

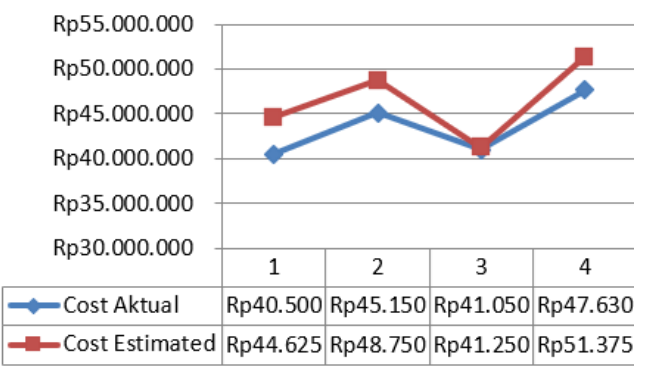

Fig. 3. Comparison of estimated and actual cost based on SRS document

\section{CONCLUSION}

The e-government system has been developed extensively in various agencies in Indonesia. However, the problem in determining cost and time for software development is one of the obstacles. Some methods are considered too complex to be implemented. This research can be one approach that can be used to solve the problem of estimating the cost of software development with methods that are simple, clear, and can be defined from the planning stage. This research offers modeling that can become a standard consideration in determining initial estimates using TOR documents and determining finer estimates using SRS documents. This research shows that the closeness of the estimated cost with the actual value based on the TOR is $81.9 \%$ whereas if based on the SRS document it is $93.4 \%$.

Documentation of application development is explained in different ways so that it influences in determining the functional value of the application. Therefore, the completeness and standard design of software development documentation have a major impact on the validity of measurements. In further research can add applications with similar characteristics so that the model can be developed in general. In addition to using FP, further research can use other estimation methods such as COCOMO 2.0, analogy, or neural network as a comparison.

\section{ACKNOWLEDGMENT}

Praise and thank the authors say to Allah Almighty for all His gifts so that this scientific work was completed. The authors gratefully acknowledge the contributions of Mr. Irman Hermadi, S.Kom, MS, Ph.D., and Mrs. Yani Hadryani, S.Si, MT, Ph.D. Also, the author's appreciation was conveyed to Dinas Komunikasi Informatika dan Persandian Kota Bogor who had helped during the research data collection. The expression of thanks is also conveyed to the father, mother, and the whole family, for all their prayers and love. Hopefully this 
scientific work useful.

\section{REFERENCES}

[1] J. Albrecht, J. E. Gaffney Jr, "Software Function, Source Lines of Code, and Development Effort Prediction: A Software Science Validation", IEEE Transactions on Software Engineering, ED-9, no.6, pp. 639-648, 1983.

[2] J. P. Alstad, "Development of Cosysmo 3.0: An Extended, Unified Cost Estimating Model for Systems Engineering", Procedia Computer Science, PP.55-62, 2019.

[3] H. Azath, R. S. D. Wahidabanu, "Efficient effort estimation system viz. Function Point and quality assurance coverage", IET Software. ED-6, no.4, pp. 335-341, 2012.

[4] N. Balaji, N. Shivakumar, V. Ananth, "Software cost estimation using function points with non algorithmic approach", Global Journal of Computer Science and Technology Software \& Data Engineering, ED13, no.8, pp. 1-4, 2013.

[5] N. E. Fenton, S. L. Pfleeger, "Software Metrics", 2nd ed, Boston, International Thomson, 1997, PP. 258-265.

[6] A. R. Irawati, "Pengukuran Fungsionalitas Perangkat Lunak Menggunakan Metode Function Point Berdasarkan Dokumentasi Desain", IJCCS. 2013. ED-7, no.2, pp.111-119, 2013.

[7] W. Jawat, "Penerapan metode konstruksi dalam mewujudkan green construction paduraksa", ED-3, no.2, pp. 61-80, 2014.

[8] D.R Jeffery, G. C. Low, and M. A. Barnes, "Comparison of Function Point Counting Techniques", IEEE Trans. software Eng, 1993. ED-19, no.5, pp.529-532, 1993.

[9] K Layne, J. Lee, "Developing fully functional E-government: A four stage", Government Information Quarterly, ED-18, PP. 122-136, 2001.

[10] W. Pradani, "Kajian Metode Perhitungan Metrik Function-Point dan Penerapannya pada Dua Perangkat Lunak yang Dipilih", Al-Azhar Indonesia Seri Sains dan Teknologi, ED-2, no.1, pp. 28-34, 2013.

[11] A. Pranatha, "Analisis Perkiraan Biaya Pembuatan Enterprise Resource", Teknik Pomits, ED-1, pp.1-6, 2012.

[12] R. S. Pressman RS, "Rekayasa Perangkat Lunak : Pendekatan Praktisi", 7th ed., Yogyakarta, Andi, 2012.

[13] P. L. Primandari, "Effort Distribution to Estimate Cost in Small to Medium Software Development Project with Use Case Points", In: The Third Information Systems International Conference, pp.78-79, 2015.

[14] R. Tripathi, "Comparative study of software cost estimation techniques", International Journal of Advanced Research in Computer Science and Software Engineering, ED-6, no.1, pp.323-328, 2016.

[15] M Uzzafer, "Bootstrap Correlation Analysis of Function Point Elements.International Journal of Database Theory and Application", ED-9, no.3, pp.11-17, 2016.

[16] X. Wei, "A Neuro-Fuzzy Model for Function Points Calibration", WSEAS Transactions On Information Science \& Applications, ED-5, no. $1,2008$.

[17] N. N. Melkior. "Evaluasi implementasi E-Government pada situs Web Pemerintah Kota Surabaya, Medan, Banjarmasin, Makassar dan Jayapura", Buana Informatika, ED-6, no.4, 2015. 